\title{
Preclassic Maya Houses and Rituals: Excavations at the Karinel Group, Ceibal
}

\author{
Jessica MacLellan
}

\begin{abstract}
The site of Ceibal was founded around the beginning of sedentary life in the Maya lowlands. Excavations at the Karinel Group within the site reveal domestic structures and ritual deposits dating to the Middle Preclassic, Late Preclassic, and Terminal Preclassic periods (c. 1000 BC-AD 300). The results complement data from Ceibal's Central Plaza and publications on early households in other regions of the lowlands, inviting future investigations of temporal and geographic variation in Preclassic Maya domestic rituals.
\end{abstract}

Keywords: household archaeology, Preclassic Maya, ritual

El sitio de Ceibal se fundó alrededor del inicio de la vida sedentaria en las tierras bajas mayas. Las excavaciones en el Grupo Karinel revelaron estructuras domésticas y depósitos rituales fechados en los periodos Preclásico medio, Preclásico tardío y Preclásico terminal (ca. 1000 aC - 300 dC). Los resultados complementan los datos provenientes de la Plaza Central de Ceibal y de publicaciones sobre residencias tempranas en otras regiones de las tierras bajas e invitan a desarrollar investigaciones sobre la variación temporal y geográfica en los rituales domésticos del Preclásico Maya.

Palabras Clave: arqueología doméstica, Preclásico Maya, ritual

$\mathrm{C}$ eibal is located on the Pasión River in southwest Peten, Guatemala. From 1964 to 1968, Harvard University's Seibal Archaeological Project conducted investigations at the site (Willey et al. 1975). The Harvard project discovered an Early Middle Preclassic (c. 1000-700 BC) occupation and defined the associated Real ceramic phase (Sabloff 1975).

From 2005 to 2016, the Ceibal-Petexbatun Archaeological Project, directed by Takeshi Inomata and Daniela Triadan, conducted additional excavations at Ceibal, focusing on the origins of Maya society (Figure 1). Based on these excavations, Inomata refined Sabloff's ceramic chronology (Table 1; Inomata 2017). Ceibal was founded around $950 \mathrm{BC}$, when the Central Plaza and the first platforms were carved out of the bedrock (sterile limestone marl and clay; Inomata et al. 2013). The foundation of this public space roughly coincides with the transition to sedentism and ceramic use in the Maya lowlands (Lohse 2010). Greenstone axes and other objects were repeatedly cached in the plaza (Inomata, Pinzón, et al. 2017). The earliest known house platforms at Ceibal date to the Real 3 ceramic phase (c. 775-700 BC), although earlier domestic structures may exist (Inomata et al. 2015; Triadan et al. 2017).

The Karinel Group is a residential platform $160 \mathrm{~m}$ west of the Central Plaza (Figure 1). The area was investigated by Gair Tourtellot during the 1960s (Tourtellot 1988:171-174). Tourtellot found that the platform was occupied during the Real ceramic phase and that the bedrock was relatively near the ground surface. For those reasons, the Karinel Group was an ideal location to expose Early Middle Preclassic domestic areas. I oversaw excavations there from 2012-2015. The team established the chronology of the Karinel Group through the analysis of stratigraphy,

Jessica MacLellan — School of Anthropology, University of Arizona, PO Box 210030, Tucson, AZ 85721-0030, USA (jessmac@email.arizona.edu)

Latin American Antiquity 30(2), 2019, pp. 415-421

Copyright (C) 2019 by the Society for American Archaeology doi:10.1017/laq.2019.15 


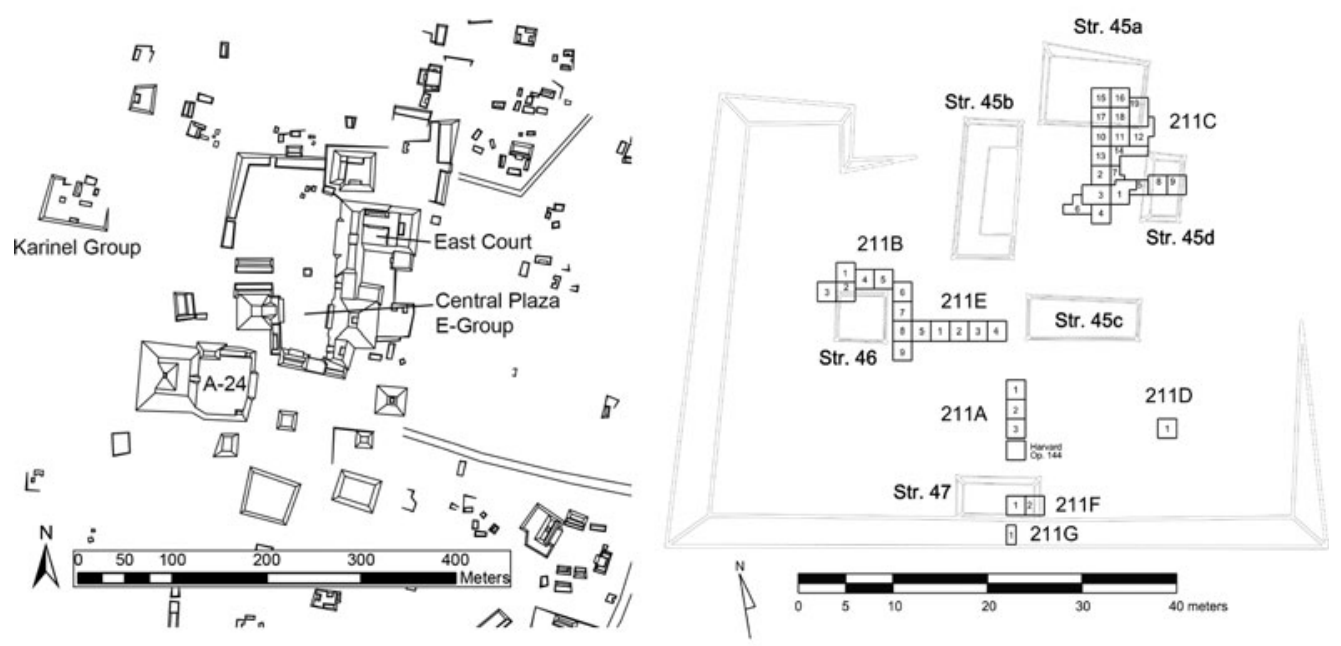

Figure 1. Left: Map of central Ceibal; right: excavations at the Karinel Group (both based on Smith 1982).

ceramic artifacts, and radiocarbon dates (Inomata, Triadan, MacLellan, et al. 2017:Table S1). I found that early domestic rituals were distinct from activities in the Central Plaza, until a transformation in ritual practices took place at the beginning of the Late Preclassic. Comparisons to published reports show that Ceibal's early household rituals had more in common with

Table 1. Preclassic Ceramic Chronology.

\begin{tabular}{lc}
\hline Ceramic Phase & Approximate Date Range \\
\hline Early Middle Preclassic & \\
Real 1 & $1000-850 \mathrm{BC}$ \\
Real 2 & $850-775 \mathrm{BC}$ \\
Real 3 & $775-700 \mathrm{BC}$ \\
Late Middle Preclassic & \\
Escoba 1 & $700-600 \mathrm{BC}$ \\
Escoba 2 & $600-450 \mathrm{BC}$ \\
Escoba 3 & $450-350 \mathrm{BC}$ \\
Late Preclassic & \\
Cantutse 1 & $350-300 \mathrm{BC}$ \\
Cantutse 2 & $300-150 \mathrm{BC}$ \\
Cantutse 3 & $150-75 \mathrm{BC}$ \\
Terminal Preclassic & \\
Xate 1 & 75 BC-AD 50 \\
Xate 2 & AD 50-125 \\
Xate 3 & AD 125-200 \\
Junco 1 & AD 200-300 \\
\hline
\end{tabular}

Note: Dating based on Inomata (2017) and Sabloff (1975). rituals in the Belize River Valley region than with those in northern Belize.

\section{Investigations at the Karinel Group}

\section{Early Middle Preclassic}

Throughout the Early Middle Preclassic and the beginning of the Late Middle Preclassic, the residents of the Karinel Group used the bedrock as a living surface. At some point during the Early Middle Preclassic, the northern edge of the basal platform was defined by carving the natural soil (Subop. 211C). The earliest evidence of occupation consists of Real 2 phase (c. 850775 BC) ceramic artifacts found in deposits on the bedrock (Subops. 211A and 211D). A charcoal sample found on the bedrock (PLD28792) was also dated to this era (Inomata, Triadan, et al. 2017:Table S1).

During the Real 3 phase, the basal platform was extended to the north. Poorly preserved walls in this area indicate the existence of Real 3 structures, and middens suggest that the structures were domestic. A low circular platform or altar, Structure Pemech-2, measured $2.8 \mathrm{~m}$ in diameter (Figures 2 and 3). Near the end of the Real 3 phase, Ceibal Monument 3, a roughly modified boulder, was placed above Structure 


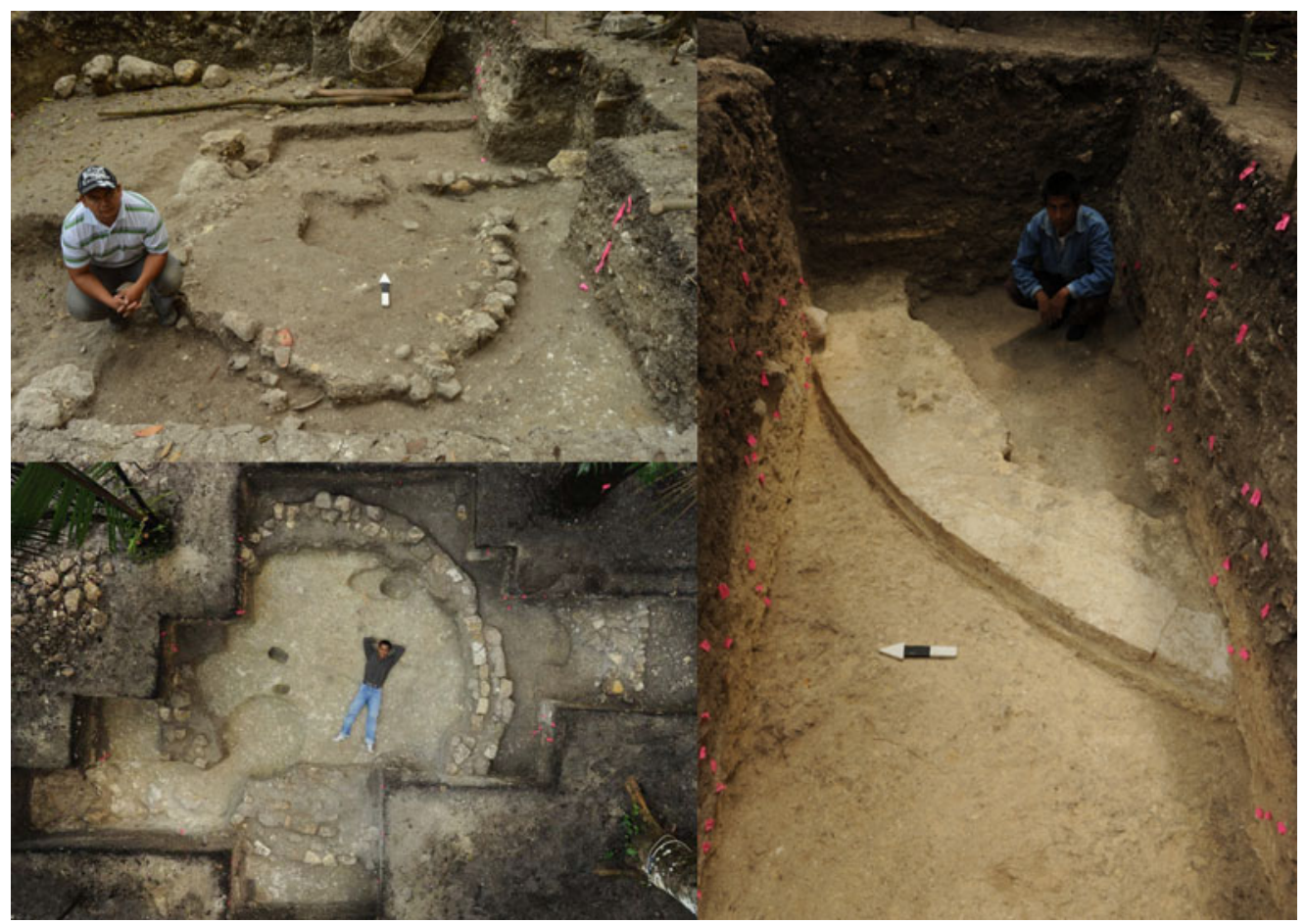

Figure 2. Top left: Str. Pemech-2; bottom left: Str. Sutsu (Inomata); right: Str. 47-Sub-3 (Inomata). (Photographs by Inomata used with permission).

Pemech-2. Monument 3 measures approximately $1 \mathrm{~m}^{3}$ and may have served as an altar. It was incorporated into later structures and remained visible throughout the Preclassic period. A similar boulder was excavated in an Early Middle Preclassic residential area at Cahal Pech in the Belize River Valley (Cheetham 1995:27).

Burial 132 was deposited in a globular chamber in the bedrock on the western side of the Karinel Group (Subop. 211B). The burial contained two adults, an infant, and seven Real 3 ceramic vessels (Palomo et al. 2017).

Fragments of ceramic figurines were recovered from Real 3 and Late Middle Preclassic middens and construction fills at the Karinel Group. Most of these figurines depict human forms. Middle Preclassic figurines may have been used in domestic rituals (Grove and Gillespie 2002; Marcus 1999).

\section{Late Middle Preclassic}

Middens confirm that the Karinel Group remained residential throughout the Late Middle Preclassic period. The earliest clear patio dates to the Escoba 1 phase, when an area of the natural soil in the northeast part of the group was leveled (Subop. 211C). On the east side of the patio, a white marl platform was constructed. This was rebuilt as a mottled red-and-white platform. Each of these structures was only a few centimeters thick. One posthole was uncovered.

During the Escoba 2 phase (c. $600-450$ BC), the red-and-white platform was covered by Structure Saqb'in-1, a platform with walls made of limestone blocks. A circular platform, Structure Sutsu, was built in the patio, $1.6 \mathrm{~m}$ west of Structure Saqb'in-1 (Figures 2 and 3). It is about $0.4 \mathrm{~m}$ tall and $5 \mathrm{~m}$ in diameter, and the outer wall is made up of two concentric rings of limestone blocks. There is no evidence of a superstructure. During the Late Middle Preclassic, similar circular platforms were constructed within domestic patio groups throughout the lowlands and probably served as stages for ritual performances (Aimers et al. 2000; Hendon 2000).

Around the same time, the basal platform of the Karinel Group was extended to the west with the addition of Structure Tz'unun. A 

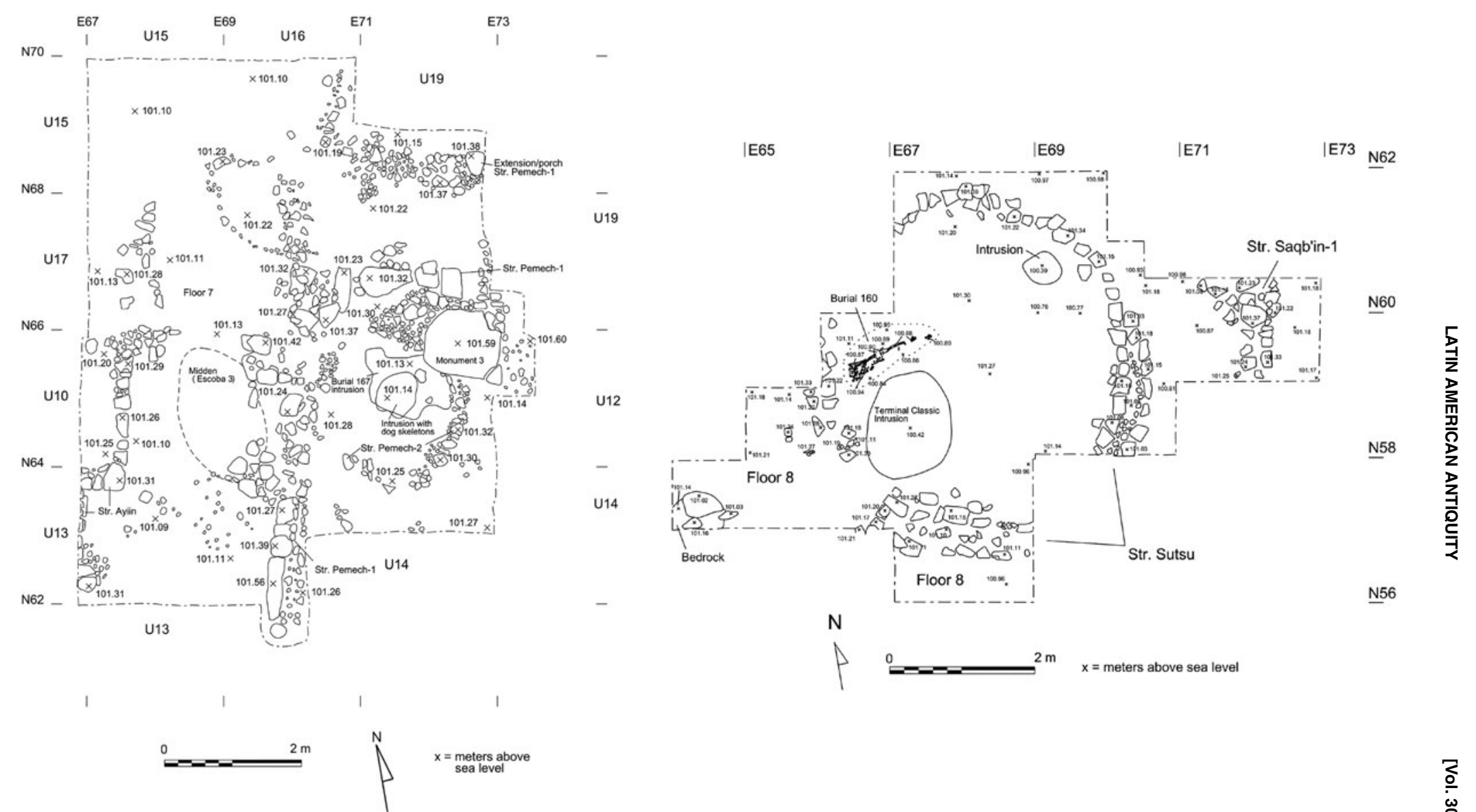

Figure 3. Left: Plan of northern Subop. 211C, showing locations of Str. Pemech-2, Monument 3, Str. Pemech-1, and Str. Ayiin; right: plan of southern Subop. 211C, showing locations of Str. Saqb'in-1, Str. Sutsu, and Burial 160. 
midden in this area contained the remnants of obsidian prismatic blade manufacture (Aoyama et al. 2017). At the end of the Escoba 2 phase, an offering (Cache 157) of an obsidian blade, an obsidian flake core, and a large fragment of a ceramic plate was left on the floor of Structure Tz'unun and covered by construction fill. Late Middle Preclassic caches of obsidian objects, associated with construction episodes, have also been found at Cahal Pech (Lee 1996:85; Lee and Awe 1995:107). At nearby Blackman Eddy, a partial ceramic vessel and shell fragments were left on the floor of a house platform (Brown et al. 2018:100). No Middle Preclassic caches were identified at Cuello and K'axob in northern Belize (Hammond 1991; McAnany 2004).

Below Structure 47 (Subop. 211F), we uncovered another round platform dated to the Escoba 2 phase: Structure 47-Sub-3. The wall of 47-Sub-3 is made up of white, soft limestone blocks and is $0.20 \mathrm{~m}$ tall (Figure 2). Its diameter is approximately $6 \mathrm{~m}$.

During the Escoba 3 phase (c. $450-350$ BC), a western extension of the basal platform was constructed over Structure Tz'unun, and a human scapula was left in a retaining wall. Two house platforms, Structure Pemech-1 and Structure Ayiin, were built on the east and west sides of the patio north of Structure Sutsu (Figure 3). These platforms were rectangular, with walls made of multiple courses of limestone blocks.

Middle Preclassic mortuary rituals at Ceibal differ greatly from those at K'axob (McAnany 2004) and Cuello (Hammond 1991), where many burials were found in house platforms. Two burials at the Karinel Group are tentatively dated to the Escoba 2 ceramic phase, although they may be older. Neither contained grave goods. As with Burial 132, these burials were not located in house platforms. Burial 128, of an adult, was found on the bedrock outside Structure Tz'unun. It was a primary burial of an adult, but the skull, left arm, both tibias, and the right femur were removed in antiquity. Two teeth were recovered. Burial 160 was found on the bedrock below Structure Sutsu, but does not appear to be intrusive into that structure (Figure 3). It was located near the edge of
Structure Sutsu, and its orientation does not relate to known architecture. Like Burial 128, this is a primary burial of an adult. The body was cut in half postdeposition, with removal of the right side of the body and the entire skull. Two teeth remained.

\section{Middle to Late Preclassic Transition}

Based on excavations at the Karinel Group and investigations by Melissa Burham in the periphery of Ceibal, rituals in residential groups became similar to those conducted in the public plaza around the time of the transition to the Late Preclassic period (Burham and MacLellan 2014). At the Karinel Group, the early patio group was filled in around $350 \mathrm{BC}$. Above the buried house platforms, an offering of a human ilium and the first cache of a complete ceramic vessel (Cache 175) were deposited in pits in an exterior floor.

\section{Late and Terminal Preclassic}

During the Cantutse 1 ceramic phase (c. $350-$ 300 BC), Structure 47-Sub-3 was replaced by the rectilinear Structure 47-Sub-2. Above the buried Middle Preclassic patio group, Structure 45a-Sub-1, a platform with a front terrace, faced south toward a plaster patio floor. Monument 3 was still visible within the platform.

During the Terminal Preclassic (Protoclassic) period (c. 75 BC-AD 300), Cache 159 was deposited on the bedrock in front of Structure 47. It contained 18 ceramic vessels placed lip to lip, an obsidian blade, and 2 limestone discs. Cache 159 dates to the Xate 1 or 2 ceramic phase and resembles Terminal Preclassic caches in the Central Plaza (Inomata, Pinzón, et al. 2017).

\section{Conclusions}

Data from the Karinel Group complement information from Ceibal's Central Plaza and from early sites in other regions of the Maya lowlands. During the Middle Preclassic period, public rituals had little in common with domestic rituals at Ceibal. In the plaza, many caches were cut into the floors, whereas domestic rituals may have involved circular platforms and ceramic figurines. Rituals at the Karinel Group differ markedly from practices at early residential groups 
in northern Belize. Greater similarity is found between the Karinel Group rituals and the household rituals at sites in the Belize River Valley. After the transition to the Late Preclassic, the residents of the Karinel Group created intrusive caches that resembled contemporaneous deposits in the Central Plaza. Figurines became rare, and circular structures were buried. This shift coincides with changes in ritual practices across the lowlands (Ringle 1999). The Karinel Group findings encourage new inquiries into variations in household ritual across the Maya area and over the course of the Preclassic period.

Acknowledgments. This research was funded by the National Science Foundation (BCS-1518794) and Alphawood Foundation (grant to Inomata and Triadan). Additional support was provided by Dumbarton Oaks and the University of Arizona (School of Anthropology, Graduate and Professional Student Council, Social and Behavioral Sciences Research Institute). Permits were granted by Instituto de Antropología e Historia, Guatemala (29-2009; 25-2013; DGPCYN-122014). Thanks to Takeshi Inomata, Daniela Triadan, and the Ceibal-Petexbatun Archaeological Project members. Inomata, Melissa Burham, Samantha Fladd, and anonymous reviewers commented on earlier versions of this article. No conflicts of interest affected this research.

Data Availability Statement. Excavated materials are stored at the Salon 3 facility in Guatemala City (contact Instituto de Antropología e Historia, 12 Ave. 11-65, Zona 1, +502 2232-5571).

\section{References Cited}

Aimers, James J., Terry G. Powis, and Jaime J. Awe

2000 Preclassic Round Structures of the Upper Belize River Valley. Latin American Antiquity 11:71-86.

Aoyama, Kazuo, Takeshi Inomata, Daniela Triadan, Flory Pinzón, Juan Manuel Palomo, Jessica MacLellan, and Ashley Sharpe

2017 Early Maya Ritual Practices and Craft Production: Late Middle Preclassic Ritual Deposits Containing Obsidian Artifacts at Ceibal, Guatemala. Journal of Field Archaeology 42:408-422.

Brown, M. Kathryn, Jaime J. Awe, and James F. Garber

2018 Ideology, Religion, \& Ritual in Social Complexity in the Belize River Valley. In Pathways to Complexity: A View from the Maya Lowlands, edited by M. Kathryn Brown and George J. Bey III, pp. 87-116. University Press of Florida, Gainesville.

Burham, Melissa, and Jessica MacLellan

2014 Thinking outside the Plaza: Ritual Practices in Preclassic Maya Residential Groups at Ceibal, Guatemala. Antiquity 88 (340). http://journal.antiquity.ac.uk/projgall/burham340.

Cheetham, David

1995 Excavations of Structure B-4, Cahal Pech, Belize: 1994 Operations. In Belize Valley Preclassic Maya
Project: Report on the 1994 Field Season, edited by Paul F. Healy and Jaime J. Awe, pp. 18-44. Occasional Papers in Anthropology 10. Trent University, Peterborough, Ontario.

Grove, David C., and Susan D. Gillespie

2002 Formative Domestic Ritual at Chalcatzingo, Morelos. In Domestic Ritual in Ancient Mesoamerica, edited by Patricia Plunket, pp. 11-19. Cotsen Institute of Archaeology Monograph 46. Cotsen Institute of Archaeology, University of California, Los Angeles.

Hammond, Norman (editor)

1991 Cuello: An Early Maya Community in Belize. Cambridge University Press, Cambridge.

Hendon, Julia A.

2000 Round Structures, Household Identity, and Public Performance in Preclassic Maya Society. Latin American Antiquity 11:299-301.

Inomata, Takeshi

2017 Emergence of Standardized Spatial Plans in Southern Mesoamerica: Chronology and Inter-regional Interaction Viewed from Ceibal, Guatemala. Ancient Mesoamerica 28:329-355.

Inomata, Takeshi, Daniela Triadan, Kazuo Aoyama, Victor Castillo, and Hitoshi Yonenobu

2013 Early Ceremonial Constructions at Ceibal, Guatemala, and the Origins of Lowland Maya Civilization. Science 340:467-471.

Inomata, Takeshi, Jessica MacLellan, Daniela Triadan, Jessica Munson, Melissa Burham, Kazuo Aoyama, Hiroo Nasu, Flory Pinzón, and Hitoshi Yonenobu

2015 Development of Sedentary Communities in the Maya Lowlands: Coexisting Mobile Groups and Public Ceremonies at Ceibal, Guatemala. PNAS 112:42684273.

Inomata, Takeshi, Flory Pinzón, Juan Manuel Palomo, Ashley Sharpe, Raúl Ortíz, María Belén Méndez, and Otto Román

2017 Public Ritual and Interregional Interactions: Excavations of the Central Plaza of Group A, Ceibal. Ancient Mesoamerica 28:203-232.

Inomata, Takeshi, Daniela Triadan, Jessica MacLellan, Melissa Burham, Kazuo Aoyama, Juan Manuel Palomo, Hitoshi Yonenobu, Flory Pinzón, and Hiroo Nasu

2017 High-Precision Radiocarbon Dating of Political Collapse and Dynastic Origins at the Maya Site of Ceibal, Guatemala. PNAS 114:1293-1298.

Lee, David

1996 Nohoch Na (The Big House): The 1995 Excavations at the Cas Pek Group, Cahal Pech, Belize. In Belize Valley Preclassic Maya Project: Report on the 1995 Field Season, edited by Paul F. Healy and Jaime J. Awe, pp. 77-97. Occasional Papers in Anthropology 12. Trent University, Peterborough, Ontario.

Lee, David, and Jaime J. Awe

1995 Middle Formative Architecture, Burials, and Craft Specialization: Report on the 1994 Investigations at the Cas Pek Group, Cahal Pech, Belize. In Belize Valley Preclassic Maya Project: Report on the 1994 Field Season, edited by Paul F. Healy and Jaime J. Awe, pp. 95-115. Occasional Papers in Anthropology 10. Trent University, Peterborough, Ontario.

Lohse, Jon C.

2010 Archaic Origins of the Lowland Maya. Latin American Antiquity 21:312-352.

Marcus, Joyce

1999 Men's and Women's Ritual in Formative Oaxaca. In 
Social Patterns in Pre-Classic Mesoamerica, edited by David C. Grove and Rosemary A. Joyce, pp. 67-96. Dumbarton Oaks, Washington, DC.

McAnany, Patricia A. (editor)

2004 K'axob: Ritual, Work, and Family in an Ancient Maya Village. Cotsen Institute of Archaeology, University of California, Los Angeles.

Palomo, Juan Manuel, Takeshi Inomata, and Daniela Triadan 2017 Mortuary Rituals and Cranial Modifications at Ceibal: From the Early Middle Preclassic to the Terminal Classic Period. Ancient Mesoamerica 28:305-327.

Ringle, William M.

1999 Pre-Classic Cityscapes: Ritual Politics among the Early Lowland Maya. In Social Patterns in Pre-Classic Mesoamerica, edited by David C. Grove and Rosemary A. Joyce, pp. 183-223. Dumbarton Oaks, Washington, DC.

Sabloff, Jeremy A.

1975 Excavations at Seibal, Department of Petén, Guatemala: Ceramics. Memoirs of the Peabody Museum of Archaeology and Ethnology Vol. 13(2). Peabody Museum of Archaeology and Ethnology, Cambridge, Massachusetts.

Smith, A. Ledyard

1982 Excavations at Seibal, Department of Peten, Guatemala: Major Architecture and Caches. Memoirs of the Peabody Museum of Archaeology and Ethnology Vol.
15(1). Peabody Museum of Archaeology and Ethnology, Cambridge, Massachusetts.

Tourtellot, Gair

1988 Excavations at Seibal, Department of Petén, Guatemala: Peripheral Survey and Excavation, Settlement and Community Patterns. Memoirs of the Peabody Museum of Archaeology and Ethnology Vol. 16(1). Peabody Museum of Archaeology and Ethnology, Cambridge, Massachusetts.

Triadan, Daniela, Victor Castillo, Takeshi Inomata, Juan Manuel Palomo, María Belén Méndez, Mónica Cortave, Jessica MacLellan, Melissa Burham, and Erick Ponciano

2017 Social Transformations in a Middle Preclassic Community: Elite Residential Complexes at Ceibal. Ancient Mesoamerica 28:233-264.

Willey, Gordon R., A. Ledyard Smith, Gair Tourtellot, and Ian Graham

1975 Excavations at Seibal, Department of Petén, Guatemala: Introduction: The Site and Its Settings. Memoirs of the Peabody Museum of Archaeology and Ethnology Vol. 13(1). Peabody Museum of Archaeology and Ethnology, Cambridge, Massachusetts.

Submitted February 27, 2018; Revised September 13, 2018; Accepted January 28, 2019 